\title{
Hormonal Regulation of Connexin 43 Expression and Gap Junctional Communication in Human Osteoblastic Cells
}

\author{
Hideki Chiba ${ }^{1,2,4}$, Norimasa Sawada ${ }^{1}$, Masahito Oyamada ${ }^{1}$, Takashi Kojima ${ }^{1}$, Kousuke Iba ${ }^{1,2}$, \\ Seiichi Ishii ${ }^{2}$, and Michio Mori ${ }^{1}$ \\ Departments of ${ }^{1}$ Pathology and ${ }^{2}$ Orthopedic Surgery, Sapporo Medical University School of Medicine, \\ Sapporo 060, Japan
}

Key words: human osteoblasts/gap junctions/connexins/retinoic acid/transforming growth factor- $\beta$

\begin{abstract}
We have recently shown that connexin $43(\mathrm{Cx} 43)$, a major gap junction protein in osteoblasts, is expressed with an increase in cell density (CHIBA, H. et al. (1993). Cell Struc. Funct., 18: 419-426). In the present study, we examined what kinds of hormones and cytokines regulate the gap junction protein in osteoblastic cells, using a human osteoblastic cell line (SV-HFO) after reaching a confluent density to avoid influence of cell proliferation. Either retinoic acid (RA) or transforming growth factor- $\beta_{1}$ (TGF- $\beta_{1}$ ) induced the Cx43 expression of SV-HFO cells, as revealed by Northern blot analysis and immunocytochemistry. These modulators also increased gap junctional intercellular communication, in terms of the extent of dye transfer. On the other hand, $1 \alpha$, 25-dihydroxyvitamin $D_{3}$ did not influence the $C x 43$ expression and gap junctional intercellular communication of the cells. These results suggest that RA and TGF- $\beta_{1}$ might maintain bone tissue as an organized tissue in vivo by increasing intercellular communication of osteoblastic cells.
\end{abstract}

Gap junctions are intercellular channels, composed of transmembrane proteins called connexins (1). By allowing transfer of ions and small molecules into neighboring cells, gap junctions are considered to play important roles in cell differentiation, proliferation and tissue organization (13). Osteoblasts and osteocytes in bone matrix in vivo are connected with each other, forming a cell-cell network via gap junctions $(8,15,18,21)$. It has become clear that connexin $43(\mathrm{Cx} 43)$ is a major gap junction protein expressed in osteoblastic cells $(6,25$, $26,27)$. We have recently observed that the expression of Cx43 in osteoblastic cells was induced with an increase in cell density (3). However, it remains unknown what kinds of hormones and cytokines regulate the expression of gap junction protein in osteoblastic cells.

Recently, we have established a human osteoblastic cell line from normal human bone by immortalization with simian virus 40 . This cell line, designated SVHFO, proliferates and maintains osteoblasic properties even under serum-free conditions as well as under serum-supplemented conditions $(2,3)$. Thus, SV-HFO cell line are expected to be a suitable model for elucidat-

\footnotetext{
${ }^{4}$ To whom reprint requests/corresrondences should be addressed. Abbreviation used: $\mathrm{Cx}$, connexin; HFO, human fetal osteoblastic cells; SV-HFO, SV40-transformed human fetal osteoblastic cells; $1,25(\mathrm{OH})_{2} \mathrm{D}_{3}, \quad 1 \alpha, 25$-dihydroxyvitamin $\mathrm{D}_{3}$; TGF- $\beta$, transforming growth factor- $\beta$; RA, retinoic acid; DMEM, Dulbecco's modified Eagle's medium; DIG, digoxigenin; ALP, alkaline phosphatase.
}

ing the effects of hormones and cytokines on the phenotypic expression of human osteoblasts. In the present study, we examined the effects of $1,25(\mathrm{OH})_{2} \mathrm{D}_{3}$, retinoic acid and transforming growth factor- $\beta$ (TGF- $\beta$ ), modulators of bone cells, on the $\mathrm{Cx} 43$ expression and gap junctional intercellular communication in SV-HFO cells.

\section{MATERIALS AND METHODS}

Cell culture. The SV-HFO cells were established as described previously $(2,3)$. The cells at passage 15 were seeded at a cell density of $1 \times 10^{4}$ cells $/ \mathrm{cm}^{2}$ on 100 - $\mathrm{mm}$ culture dishes or 12-well tissue culture plates coated with $2 \mu \mathrm{g} / \mathrm{cm}^{2}$ type I collagen (Vitrogen 100; Collagen Corp., Palo Alto, CA) in serum-free Dulbecco's modified Eagle's medium (DMEM; Nissui Pharmaceutical, Tokyo, Japan) supplemented with $0.5 \%$ bovine serum albumin (Albumax; Gibco Laboratories, Grant Island, NY), ITS (containing $5 \mu \mathrm{g} / \mathrm{ml}$ insulin, $5 \mu \mathrm{g} / \mathrm{ml}$ transferrin and $5 \mathrm{ng} / \mathrm{ml}$ selenious acid; Collaborative $\mathrm{Re}-$ search, Inc., Bedford, MA), $100 \mathrm{U} / \mathrm{ml}$ penicillin and $100 \mu \mathrm{g}$ $/ \mathrm{ml}$ streptomycin (Gibco Laboratories). These cells were cultured at $37^{\circ} \mathrm{C}$ in a humidified atmosphere of $5 \% \mathrm{CO}_{2}$ in air, and the medium was renewed every 3 days. To determine the effects of $1,25(\mathrm{OH})_{2} \mathrm{D}_{3}$ (Biomol Research Laboratories, Inc., Plymouth Meeting, PA), all-trans retinoic acid (RA) or TGF$\beta_{1}$ (Sigma Chemical Co., St. Louis, MO) on the Cx43 expression and gap junctional intercellular communication, the cells 
reaching a confluent density on $35-\mathrm{mm}$ or $100-\mathrm{mm}$ culture dishes were treated with $10^{-7} \mathrm{M} 1,25(\mathrm{OH})_{2} \mathrm{D}_{3}, 10^{-7} \mathrm{M}$ RA or $5 \mathrm{ng} / \mathrm{ml} \mathrm{TGF}-\beta_{1}$ for $6,12,24$ or 48 consecutive hours. The stock solution of $1,25(\mathrm{OH})_{2} \mathrm{D}_{3}$ was in ethanol, and that of RA was in dimethyl sulfoxide (DMSO). Both test and control solutions contained the same concentration of ethanol or DMSO, which was less than $0.1 \%$.

Northern blot analysis. Total RNAs were isolated from cell cultures using the single-step thiocyanate-phenol-chloroform extraction method (5) as modified by Xie and Rothblum (30). For electrophoresis, $10 \mu \mathrm{g}$ of total RNAs was loaded on $1 \%$ agarose gel containing $0.5 \mu \mathrm{g} / \mathrm{ml}$ ethidium bromide. Gels were capillary-blotted in $20 \times$ saline sodium citrate (SSC) onto nylon membranes (Hybond-N; Amersham Corp., Buckinghamshire, England) and fixed by UV light.

For the detection of Cx43 mRNA, digoxigenin (DIG)-labeled RNA probes were prepared from rat cDNA using an RNA labeling kit (Boehringer Mannheim, Mannheim, Germany), and hybridization, washing and chemiluminescent detection were carried out following the DIG luminescent protocol (14).

Immunocytochemistry. SV-HFO cells were cultured on cover-slips coated with $2 \mu \mathrm{g} / \mathrm{cm}^{2}$ type I collagen under the serum-free condition. After reaching confluence, the cells were incubated in the presence or absence of $10^{-7} \mathrm{M} 1,25(\mathrm{OH})_{2} \mathrm{D}_{3}$, $10^{-7} \mathrm{M}$ RA or $5 \mathrm{ng} / \mathrm{ml}$ TGF- $\beta_{1}$ for 24 hours. These cells were then rinsed with phosphate-buffer saline (PBS), fixed in acetone for $20 \mathrm{~min}$ at $-20^{\circ} \mathrm{C}$, and the presence of $\mathrm{Cx} 43$ was investigated by the procedure described before $(3,23)$. Briefly, the fixed cells were incubated with rabbit polyclonal antibody against $\mathrm{Cx} 43$ peptides (1/100 dilution) for $1 \mathrm{~h}$ at room temperature. After washing with PBS, the cells were reacted with swine fluorescein-conjugated anti-rabbit immunoglobulin (1 /100 dilution; DAKO, Copenhagen, Denmark) for $1 \mathrm{~h}$, rinsed with PBS, mounted with Mowiol 4-88 polyvinyl alcoholbased medium (Hoechst, Frankfurt, Germany), and examined under a fluorescent microscope.

Analysis of gap-junctional intercellular communication. Gap junctional intercellular communication was assayed using the scrape-loading/dye transfer technique of El-Fouly et al. (9). In brief, the cells were rinsed with PBS, scrapeloaded using a razor blade, and supplied with a $0.05 \%$ solution of the gap junction-permeable dye, Lucifer yellow (Polysciences, Inc., Warrington, PA), and the gap junction-impermeable dye, rhodamine dextran (Molecular Probes, Inc., Eugene, OR), in PBS. After leaving these cells in dye solution for $2 \mathrm{~min}$ at room temperature, the cells were rinsed with PBS several times, and examined under a fluorescent microscope. The extent of gap-junctional intercellular communication was calculated as the total number of Lucifer yellow-labeled cells per $350 \mu \mathrm{m}$ field/ the number of rhodamine dextran-labeled cells in the same field (19). Measurement were from 10 consecutive $350 \mu \mathrm{m}$ fields of at least 3 petri dishes per condition.

\section{RESULTS}

To minimize the influence of cell proliferation on the Cx43 expression (3), the cells, after reaching a confluent cell density, were used. In addition, to exclude the effect of serum on the expression, the cells were cultured under the serum-free conditions.

The expression of Cx43 mRNA was significantly induced by $10^{-7} \mathrm{M}$ RA time-dependently for at least 24 hours, with the maximal increase at 6 hours. $\mathrm{Cx} 43$ mRNA expression was also enhanced at 6,12 and 24 hours after treatment with $5 \mathrm{ng} / \mathrm{ml}$ TGF- $\beta_{1}$ (Figs. 1 and 2 ). The effects of RA and TGF- $\beta_{1}$ on Cx43 mRNA expression were also dose-dependent (data not shown). In contrast, the levels of $\mathrm{Cx} 43$ mRNA expression did not change during $1,25(\mathrm{OH})_{2} \mathrm{D}_{3}$ treatment (Figs. 1 and 2).

Immunocytochemically, $\mathrm{Cx} 43$ was demonstrated as macular spots on cell membranes between adjacent cells. Immunoreactive spots were not detected in cells incubated with preimmune serum (data not shown). Either $10^{-7} \mathrm{M}$ RA or $5 \mathrm{ng} / \mathrm{ml} \mathrm{TGF}-\beta_{1}$ significantly induced Cx43-positive spots in SV-HFO cells (Fig. 3). On the other hand, $1,25(\mathrm{OH})_{2} \mathrm{D}_{3}$ did not influence the number of Cx43-positive spots.

Figure 4 shows fluorescent photomicrographs demonstrating the intercellular transfer of Lucifer yellow dye

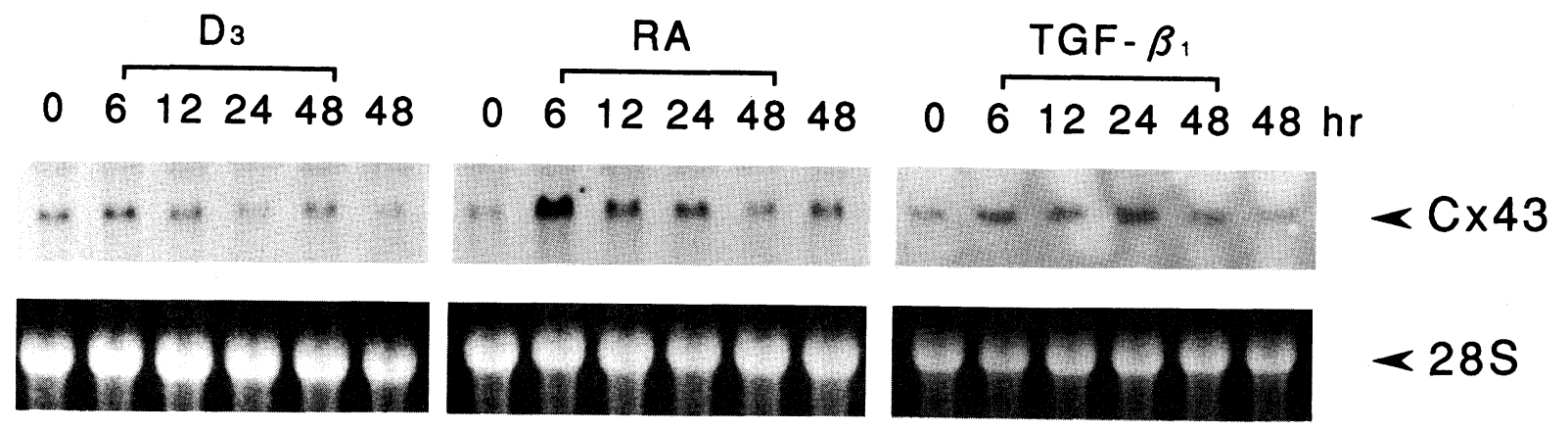

Fig. 1. Northern blot analysis of the transcript of $\mathrm{Cx} 43$ gene $(3.0 \mathrm{~kb})$ after treating confluent SV-HFO cells with $10^{-7} \mathrm{M} 1,25(\mathrm{OH})_{2} \mathrm{D}_{3}, 10^{-7} \mathrm{M}$ RA, $5 \mathrm{ng} / \mathrm{ml}$ TGF $-\beta_{1}$, or vehicle only. The bottom panel shows the ethidium bromide stain of the filter corresponding to $28 \mathrm{~S}$ ribosomal RNA. 

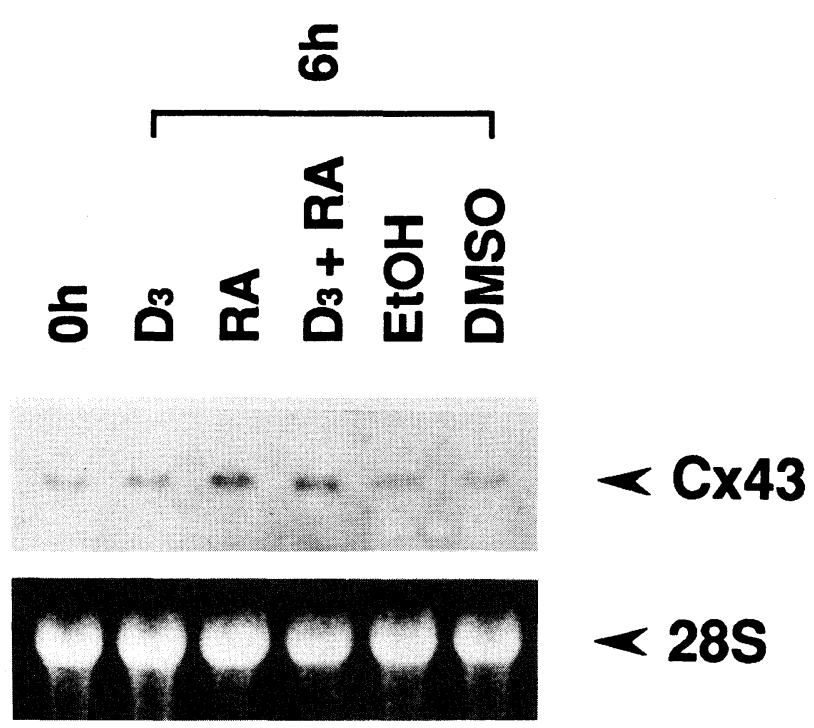

Fig. 2. Northern blot analysis of the transcript of $\mathrm{Cx} 43$ gene 6 hours after treating confluent SV-HFO cells with $10^{-7} \mathrm{M}$ $1,25(\mathrm{OH})_{2} \mathrm{D}_{3}, 10^{-7} \mathrm{M} \mathrm{RA}$, a combination of the two, $0.1 \% \mathrm{EtOH}$ or $0.1 \%$ DMSO. The bottom panel shows the ethidium bromide stain of the filter corresponding to $28 \mathrm{~S}$ ribosomal RNA.

from scraped-loaded SV-HFO cells to contiguous cells. In control culture, a little transfer of Lucifer yellow dye is detectable, indicating that only limited gap-junctional intercellular communication are present. Treating the cells with $10^{-7} \mathrm{M}$ RA or $5 \mathrm{ng} / \mathrm{ml}$ TGF- $\beta_{1}$ for 6,12 and 24 hours significantly increased the extent of Lucifer yellow transfer in terms of the gap-junctional intercellular communication, while it did not influence the extent of rhodamine dextran transfer. The number of coupled cells increased 2.2 -fold $(\mathrm{P}<0.001)$ or 2.6 -fold $(\mathrm{P}<$ 0.001 ) after 12 hours exposure to $10^{-7} \mathrm{M} \mathrm{RA}$ or $5 \mathrm{ng}$ $/ \mathrm{ml} \mathrm{TGF}-\beta_{1}$. In contrast, $1,25(\mathrm{OH})_{2} \mathrm{D}_{3}$ did not change the extent of dye transfer. These data were consistent with the results obtained from Northern blot analysis and immunocytochemistry.

\section{DISCUSSION}

The SV-HFO cell line is a new model for studying the differentiation and proliferation of human osteoblastic cells. The SV-HFO cells were immunocytochemically positive for vimentin but negative for keratin and epithelial membrane antigen, which suggested that they were of mesenchymal origin. Phase-contrast microscopic and electron microscopic observations supported the mesenchymal nature of these cells. Osteoblastic nature was indicated by evidence showing that the cells produce ALP and osteocalcin and respond to $1,25(\mathrm{OH})_{2} \mathrm{D}_{3}$ (2). We have also observed that the cells have a potential to form mineralized tissues in vitro (in preparation).

Gap junctions are implicated in metabolic cooperation, differentiation and growth of cells (13). It has been shown that $\mathrm{Cx} 43$ is a major gap junction protein in osteoblasts, and that the Cx43 expression is correlated with the extent of intercellular communication $(6,25,26$, 27). We have recently found that the $C x 43$ expression in osteoblasts is associated with an increase in cell density (3). However, the mechanism regulating $\mathrm{Cx} 43$ expression in osteoblasts remains unknown, except for the ob-
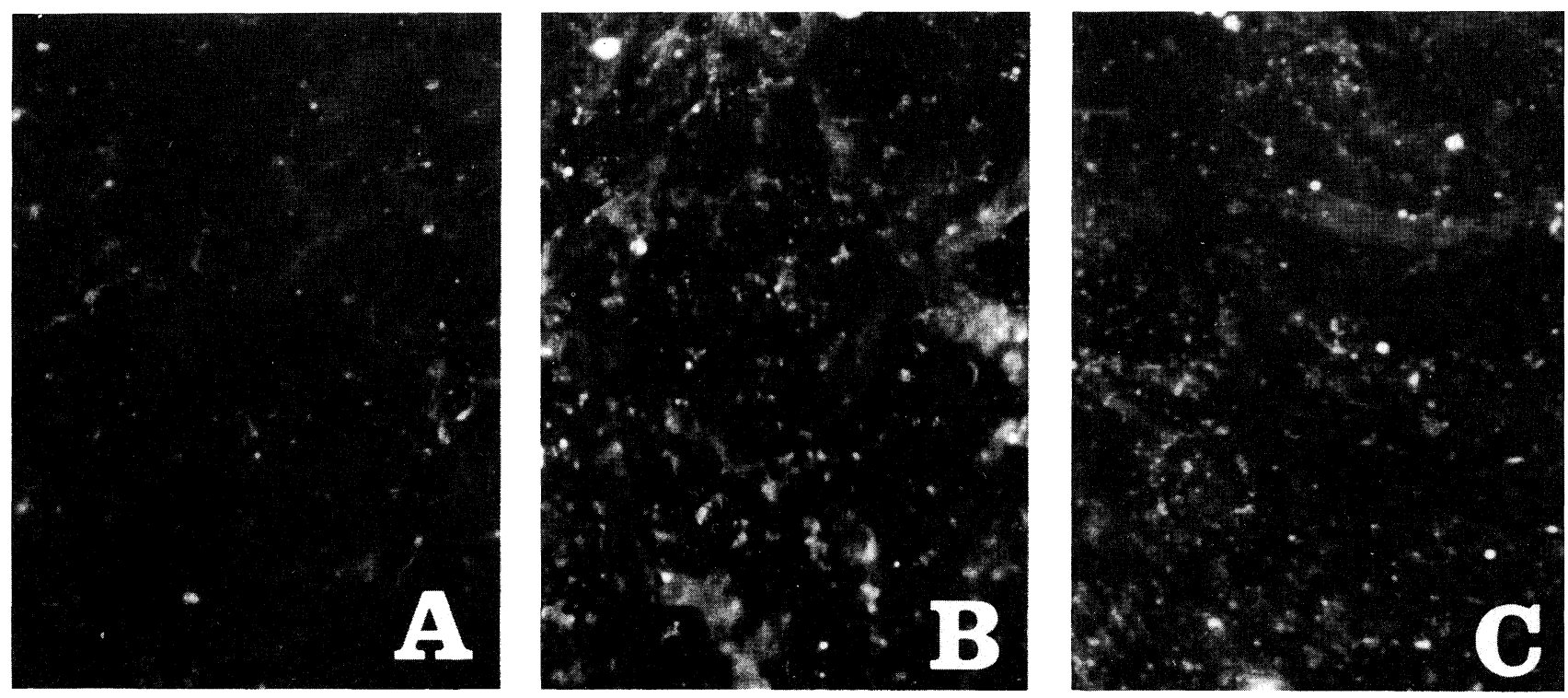

Fig. 3. Immunofluorescent staining of $\mathrm{Cx} 43$ in SV-HFO cells cultured in the absence (A) or presence of $10^{-7} \mathrm{M} \mathrm{RA}(\mathrm{B})$ and $5 \mathrm{ng} / \mathrm{ml} \mathrm{TGF}-\beta_{1}$ for 24 fours $(C)$. 

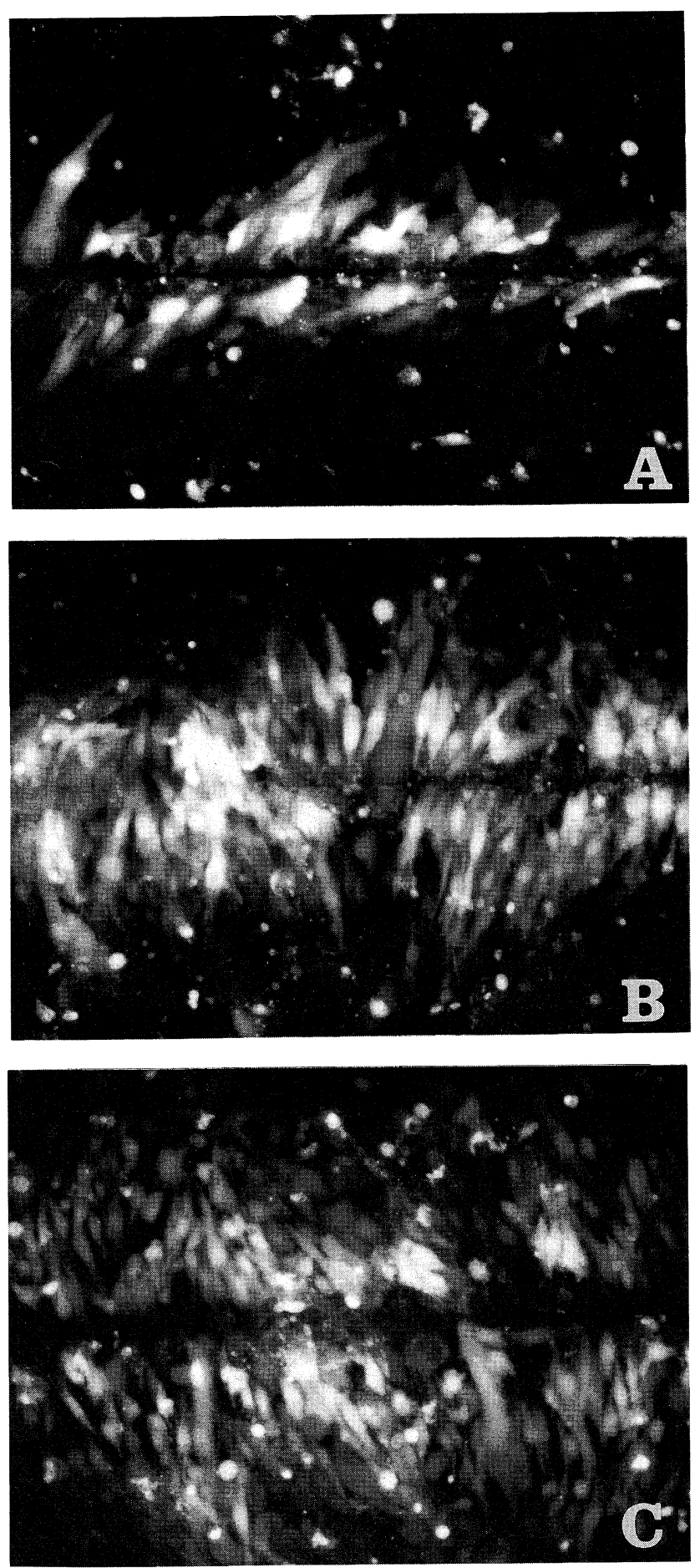

Fig. 4. Fluorescent photomicrographs demonstrating the intercellular transfer of Lucifer yellow dye via gap junctions in SV-HFO cells cultured in the absence (A) or presence of $10^{-7} \mathrm{M} \mathrm{RA}(\mathrm{B})$ and $5 \mathrm{ng} / \mathrm{ml}$ TGF- $\beta_{1}$ for 12 hours (C). servation that parathyroid hormone enhances $\mathrm{Cx} 43$ expression in osteoblastic cells (25).

In this study, we have shown that $\mathrm{Cx} 43$ expression and gap junctional communication in SV-HFO cells is enhanced by RA treatment, but not by $1,25(\mathrm{OH})_{2} \mathrm{D}_{3}$. Gap junctional intercellular communication and the expression of connexins are shown to be altered by retinoids $(12,17,20,22,24,29)$. To achieve function, RA and $1,25(\mathrm{OH})_{2} \mathrm{D}_{3}$ are required to bind to their receptors complex to responsive elements $(7,10,11,16,31)$. These findings suggest the possibility that RA functions as a crucial modulator of Cx expression via an RA-responsive element located at the upstream $5^{\prime}$ flanking region of the $\mathrm{Cx}$ gene, whereas the gene lacks a vitamin D-responsive element.

We have shown that TGF- $\beta_{1}$ up-regulates Cx43 expression and gap junctional communication in SVHFO cells. This is in contrast to previous findings which showed that canalicular cell proces formation of mouse osteoblast-like cells on the reconstituted basement membrane (Matrigel) is blocked by TGF- $\beta$, and recovered by treatment with antibodies against TGF- $\beta$ (28). Although the reason for the inconsistency is not clear, it may come from differences in culture conditions, in particular extracellular matrix.

The expression of alkaline phosphatase (ALP) in SVHFO cells was significantly induced by $1,25(\mathrm{OH})_{2} \mathrm{D}_{3}$, and suppressed by RA and TGF- $\beta_{1}$. The expression of osteocalcin, a bone-specific protein, was up-regulated by treating the cells with $1,25(\mathrm{OH})_{2} \mathrm{D}_{3}$ and RA, while down-regulated by TGF- $\beta_{1}(4)$. On the other hand, we have observed that the mineralization of SV-HFO cells was markedly reduced by treating these cells with RA or TGF- $\beta_{1}$ (unpublished data). These findings mean that there might be no direct relationship between gap junctional intercellular communication and osteoblast differentiation. To clarify the role of gap junctional communication during osteoblast differentiation, more detailed experiments are required.

In conclusion, we have demonstrated in the present study that RA and TGF- $\beta_{1}$ regulate the $\mathrm{Cx} 43$ expression and gap junctional communication of a human osteoblastic cell line.

Acknowledgments. We are grateful to Dr. D. Paul (Harvard Medical School, Boston, MA, USA), for Cx43 cDNA, and Dr. F. Ueda (Nippon Shinyaku Co., Kyoto, Japan), for anti-Cx43 antibody. We also wish to thank Drs. Y. Oyamada and H. Isomura for their valuable advice. This work was supported by Grants-in-Aid for Scientific Research and Cancer Research from the Ministry of Education, Science and Culture, from the Ministry of Health and Welfare, Japan, and from the Hokkaido Geriatrics Research Institute. 


\section{REFERENCES}

1. Beyer, E.C., Paul, D.L., and Goodenough, D.A. 1990. Connexin family of gap junction proteins. J. Membr. Biol., 116: 187-194.

2. Chiba, H., Sawada, N., Ono, T., Ishit, S., and Mori, M. 1993. Establishment and characterization of an SV40-immortalized osteoblastic cell line from normal human bone. Jpn. J. Cancer Res., 84: 290-297.

3. Chiba, H., Sawada, N., Oyamada, M., Kojima, T., Nomura, S., IsHII, S., and MoRI, M. 1993. Relationship between the expression of the gap junction protein and osteoblast phenotype in a human osteoblastic cell line during cell proliferation. Cell Struc. Funct., 18: 419-426.

4. Chiba, H., Sawada, N., Iba, K., Isomura, H., Ishit, S., and MoRI, M. 1993. A newly established cell line from normal human bone responds to $1 \alpha, 25$-dihydroxyvitamin $\mathrm{D}_{3}$, retinoic acid and transforming growth factor- $\beta_{1}$. Tumor Res., 28: 41-50.

5. Chomczynski, P. and SaCchi, N. 1987. Single-step method of RNA isolation by acid guanidinium thiocyanate-phenolchloroform extraction. Anal. Biochem., 162: 156-159.

6. Civitelli, R., Beyer, E.C., Warlow, P.M., Robertson, A., Geiat, S.T., and SteinberG, T.H. 1993. Connexin 43 mediates direct intercellular communication in human osteoblastic cell networks. J. Clin. Invest., 91: 1888-1896.

7. De LuCA, L.M. 1991. Retinoids and their receptors in differentiation, embryogenesis, and neoplasia. FASEB J., 5: 29242933.

8. Doty, S.B. 1981. Morphological evidence of gap junctions between bone cells. Calcif. Tissue Int., 33: 509-512.

9. El-Fouly, M.H., Trosko, J.E., and Chang, C-C. 1987. Scrape-loading and dye transfer. A rapid and simple technique to study gap junctional intercellular communication. Exp. Cell Res., 168: 422-430.

10. Evans, R.M. 1988. The steroid and thyroid hormone receptor superfamily. Science, 240: 889-895.

11. Green, S. and Chambon, P. 1988. Nuclear receptors enhance our understanding of transcription regulation. Trends. Genet., 4: 309-314.

12. Guo, H., Acevedo, P., Parsa, F.D., and Bertram, J.S. 1992. Gap-junctional protein connexin 43 is expressed in dermis and epidermis of human skin: differentiation modulation by retinoids. J. Invest. Dermatol., 99: 460-467.

13. Hertzberg, E. and Johnson, R. 1988. Gap Junctions. Modern Cell Biology (Vol. 7). Alan R. Liss, Inc., New York.

14. Höltke, H.J., Sanger, G., Kessler, C., and Schmitz, G. 1992. Sensitive chemiluminescent detection of digoxigenin-labeled nucleic acids: a fast and simple protocol and its applications. BioTechniques, 12: 104-113.

15. Jeansonne, B.G., Feagin, F.F., McMinn, R.W., Shoemaker, R.L., and REHM, W.S. 1979. Cell-to-cell communication of osteoblasts. J. Dent. Res., 58: 1415-1423.

16. Leid, M., Kastner, P., and Chambon, P. 1992. Multiplicity generates diversity in the retinoic acid signaling pathways. Trends. Biochem. Sci., 17: 427-433.

17. Mehta, P.P., Bertram, J.S., and Loewenstein, W.R. 1989. The actions of retinoids on cellular growth correlated with their actions on gap junctional communication. J. Cell Biol., 108: 1053-1065.
18. Miller, S.C., Bowman B.M., Smith, J.M., and Jee, W.S.S. 1980. Characterization of endosteal bone-lining cells from fatty marrow bone sites in adult beagles. Anat. Rec., 198: 163173.

19. Pepper, M.S., Montesano, R., El Aoumari, A., Gros, D., OrCI, L., and MedA, P. 1992. Coupling and connexin 43 expression in microvascular and large vessel endothelial cells. $\mathrm{Am}$. J. Physiol., 262: C1246-C1257.

20. Pitts, J.D., Hamilton, A.E., Kam, E., Burk, R.R., and MURPHY, J.P. 1986. Retinoic acid inhibits junctional communication between animal cells. Carcinogenesis, 7: 10031010.

21. Plaumbo, C., Palazzini, S., and Marotti, G. 1990. Morphological study of intercellular junctions during osteocyte differentiation. Bone, 11: 401-406.

22. RIVEDAL, E. and SANNER, T. 1992. Regulation of gap junctional communication in Syrian hamster embryo cells by retinoic acid and 12-0-tetradecanoylphorbol-13-acetate. Carcinogenesis, 13: 199-203.

23. Sakamoto, H., Oyamada, M., Enomoto, K., and Mori, M. 1992. Differential changes in expression of gap junction proteins connexin 26 and 32 during hepatocarcinogenesis in rats. Jap. J. Cancer Res., 83: 1210-1215.

24. Sato, M. and ENомото, K. 1991. Study of differentiation in human hepatoblastoma cells: Changes in cell properties by differentiation-inducing agents and co-culture with fibroblastic cells. Sapporo. Med. J., 60: 173-182.

25. Schiller, P.C., Mehta, P.P, Ross, B.A., and Howard, G.A. 1992. Hormonal regulation of intercellular communication: parathyroid hormone increases connexin 43 gene expression and gap-junctional communication in osteoblastic cells. Mol. Endocrinol., 6: 1433-1440.

26. Schirrmacher, K., Schmitz, I., Winterhager, E., Traub, O., BRUMmer, F., Jones, D., and Bingmann, D. 1992. Characterization of gap junctions between osteoblast-like cells in culture. Calcif. Tissue Int., 51: 285-290.

27. Steinberg, T.H., Civitelli, R., Geist, S.T., Robertson, A.J., Hick, E., Veenstra, R.D., Wang, H-Z, Warlow, P.M., Westphale, E.M., Laing, J.G., and Beyer, E.C. 1994 . Connexin 43 and connexin 45 from gap junctions with different molecular permeabilities in osteoblastic cells. EMBO. J., 13: 744750.

28. Vukicevic, S., Kleiman, H.K., Luyten, F.P., Roberts, A.B., Roche, N.S., and REDDI, A.H. 1992. Identification of multiple active growth factors in basement membrane matrigel suggests caution in interpretation of cellular activity related to extracellular matrix components. Exp. Cell. Res., 202: 1-8.

29. Willecke, K., Heynkes, R., Daht, E., Stutenkemper, R., Hennemann, H., Jungbluth, S., Suchyna, T., and Nicholson, B.J. 1991. Mouse connexin 37: cloning and functional expression of a gap junction gene highly expressed in lung. J. Cell Biol., 114: 1049-1057.

30. XIE, W. and Rothblum, L.I. 1991. Rapid, small-scale RNA isolation from tissue culture cells. BioTechniques, 11: 325-327.

31. YU, V.C., NAAR, A.M. and Rosenfeld, M.G. 1992. Transcriptional regulation by the nuclear receptor superfamily. Curr. Opin. Biotech., 3: 597-602.

(Received for publication, March 15, 1994

and accepted April 18, 1994) 